\title{
Visual Cultures of Secrecy in Early Modern Europe
}


Habent sua fata libelli

\section{EARLY MODERN STUDIES SERIES}

\section{GENERAL EDITOR \\ MICHAEL WOLFE}

St. John's University

\section{EDITORIAL BOARD OF EARLY MODERN STUDIES}

Elaine BeIliN
Framingham State College

Christopher Celenza Johns Hopkins University

Barbara B. Diefendorf

Boston University

PAula Findlen

Stanford University

Scott H. HendRIX

Princeton Theological Seminary

Jane Campbell Hutchison

University of Wisconsin-Madison

Mary B. McKinley

University of Virginia
Raymond A. Mentzer

University of Iowa

Charles G. Nauert

University of Missouri, Emeritus

ROBERT V. SCHNUCKeR

Truman State University, Emeritus

Nicholas Terpstra

University of Toronto

MArgo TodD

University of Pennsylvania

James Tracy

University of Minnesota

Merry Wiesner-Hanks

University of Wisconsin-Milwaukee 


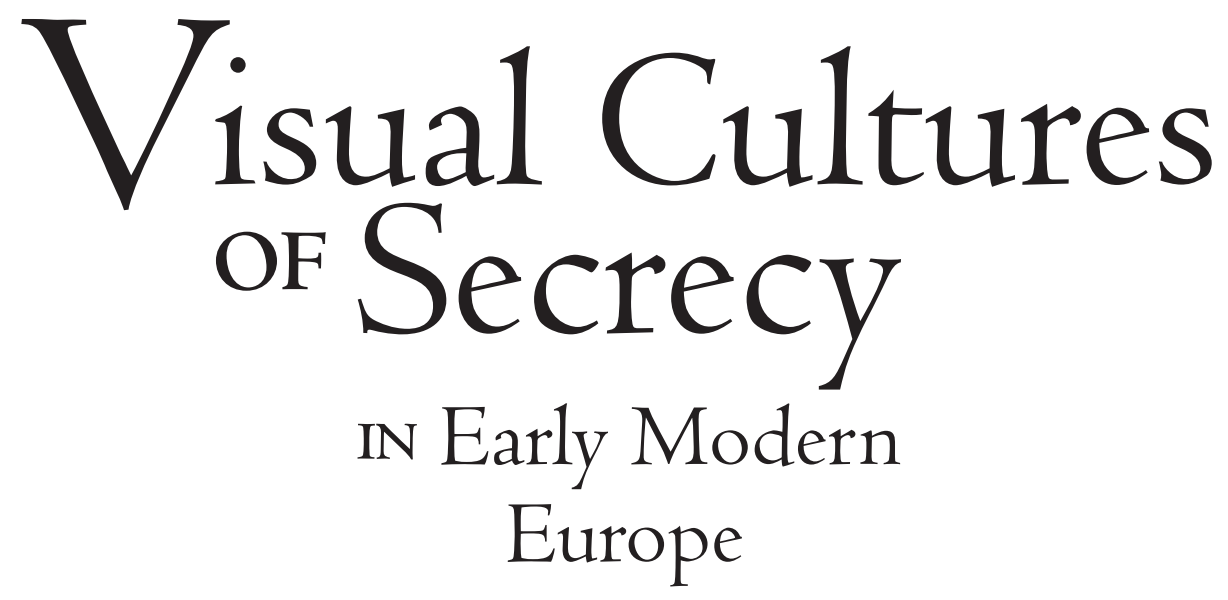

EDITED BY

Timothy McCall, Sean Roberts, and Giancarlo Fiorenza

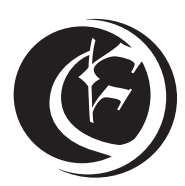

Early Modern Studies 11

Truman State University Press

Kirksville, Missouri 
Copyright (C) 2013 Truman State University Press, Kirksville, Missouri, 63501

All rights reserved

tsup.truman.edu

Cover art by Andrea Mantegna, Ludovico Gonzaga Confers with a Trusted Secretary, detail from the Camera Picta, 1465-74, fresco, Mantua, Castello di San Giorgio. Scala / Art Resource, NY.

Cover design: Teresa Wheeler

\section{Library of Congress Cataloging-in-Publication Data}

Visual cultures of secrecy in early modern Europe / edited by Timothy McCall, Sean Roberts, and Giancarlo Fiorenza. pages cmm. - (Early modern studies ; vol. 11)

Includes bibliographical references and index.

ISBN 978-1-61248-092-3 (pbk. : alk. paper) — ISBN 978-1-61248-093-0 (ebook)

1. Secrecy in art. 2. Arts, European-Themes, motives. 3. Arts and society-Europe. I. McCall, Timothy, editor of compilation. II. Roberts, Sean E., editor of compilation. III. Fiorenza, Giancarlo, 1970-, editor of compilation. NX650.S435V57 2013

$709.4-\mathrm{dc} 23$

No part of this work may be reproduced or transmitted in any format by any means without written permission from the publisher.

The paper in this publication meets or exceeds the minimum requirements of the American National Standard for Information Sciences_-Permanence of Paper for Printed Library Materials, ANSI Z39.48-1992. 